\title{
Countermeasures to Chinese Higher Animation Education: From the perspective of the Industrial Cluster
}

\author{
Su Feng \\ Institute of Animation Industry \\ Northeastern University at Qinhuangdao \\ Qinhuangdao, Hebei Province, China
}

\author{
Luo Xiaoyi \\ Graduate School of Economics \\ Kyushu University \\ Fukuoka, Japan
}

\begin{abstract}
China Higher Animation Education as important part of animation industry cluster on the basis of Industrial Cluster Theory. Firstly, the paper discusses the Supply-Demand problem from the perspective of world animation education mode against the Structural Contradiction of animation talent through analyzing the current state of China Higher Animation Education and animation talent training, and the developing phase of China animation industry. Secondly, the paper argues that higher animation education should supply qualified animation talent in accordance with the demand of animation industry by practical integration of animation ontology, discipline scope, talent structure in order to achieve the harmonious interaction between university and animation industry. At last, this paper indicates the development countermeasure of higher animation education, creating a new path for China Higher Animation Education and talent training.
\end{abstract}

Keywords-Industrial Cluster; Higher Animation Education; Structural Contradiction; Causes; Countermeasure

The development of animation industry, as of 2004, has been one of China's national strategies, along with which, the animation education has also experienced a rapid development. However, since 2010, a large number of animation graduates face difficulties for employment. At the same time, it is difficult for the animation enterprise to recruit qualified person. It implicates that the structural contradiction arises between the talent demand from the industry and the talent supply from college. What is it that leads to this dilemma? How to resolve the problem? According to the development trends of worldwide animation education, this paper dissects the current status of Chinese animation education as well as the cause underneath. Furthermore, this paper proposes some countermeasures on developing Chinese higher animation education in order to coordinate the supply and demand of animation talent.

\section{I.CURRENT STATUS: STRUCTURAL CONTRADICTION}

According to the information conveyed from regional animation recruitment resources in recent years, the incoordination problem between animation education and industrial demand increases in severity. On one side of the labor market, animation enterprise cannot recruit qualified personnel, while on the other side, nobody shows interest in graduates majored in animation. Here is one typical example that happened during the Sixth China International Animation Festival (April 20th to May 3rd, 2010, Hangzhou), on the recruitment fair of which 2000 vacancies from 55 enterprise was provided, however, few matches were made in spite of the attractive payment. The example indicates that both sides of the animation talent market are in an awkward position. Similar situations also happened in the eastern and mid-western areas.

\section{II.CAUSE: DISLOCATION IN DEVELOPMENT}

How to resolve this structural contradiction? Our analysis is started with the specific development courses of animation education and industry, as well as their interaction, aiming to figure out the cause of existing problems.

\section{A. Supply: Mis-preparation of college graduates}

During the nearly 50 years, from 1952 to 2000, only Beijing Film Academy educated animation artistic talents, with the enrolment of only 41 undergraduate students. As of 2004, the flourishing of animation industry greatly spurred the demand for animation professionals. Therefore, colleges/universities rushed into the opening of animation majors. Within less than a decade, the scale of animation education has ranked the first in the world, coming from nearly none to 447 colleges/universities.

Among all the universities/colleges, the education mainly is categorized into three kinds of model:

- Comprehensive Model. Beijing Film Academy is a template of this model, which aims to cultivate creative and versatile talent with independent screenplay and direct capacity, stressing overall performance cultivation. At present, the majority of our animation education institution belongs to this category.

- Industry-oriented model. A typical representative is Sichuan Fine Arts Institute, which emphasizes interaction of book knowledge and practical knowledge, in order to educate practical talent.

- $\quad$ Skill-based mode. This mode is mainly applied at the secondary school and vocational school. Contrary to the first mode, the aim of this model is to train practical professionals, more specifically, skilled technicians for the animation enterprise. Such schools in the third category account for about $10 \%$ nowadays.

Such an education structure forms an "inverted pyramid", gathering intense masters at the top, but lacking technicians at the bottom. Without doubt, this education structure places "cart before the horse", going beyond the actual faculty capacity as well as the current stage of 
animation industry. The gap between talent supply and demand cannot be bridged under this structure.

\section{B. Demand: infancy of management of animation} industry

Since 2004, the development of animation has become one of the national strategies. This change pushed forward the process of development, but also brought deformation and overexpansion. In fact, since the marketization experience of our animation industry is only around a decade, many aspects of the market are not mature and solid enough to bear such a "blowout" growth rate. As for the decision- makers and opinion leaders with artistic background, their management capacity needs to be improved. While the whole industry, which is still in its infancy, needs refinement by the market.

The immature management capacity leads to some extent of misunderstanding about the demand and requirement of talent, which misleads the direction of education and talent cultivation. Meanwhile, the mismatch between the growth rate of industry scale and graduates brings obstacle to the placement of the surplus of graduates in the industry, resulting in the imbalance between the two sides in animation labor market.

\section{Supply and demand: mismatch between education and industry demand}

The mismatch between the supply and demand shows in three ways.

- $\quad$ Mismatch between higher educated graduates and capacity of industry

It is estimated that the annual increase of new job opportunity in animation industry is about 10,000 , which is not a small increase once we realize that the overall practitioners are only about 200,000. One part of the candidates who compete for these 10,000 positions comes from the 100,000 graduates from 447 colleges/ universities, while the other part is from the vocational training from animation companies. It should be noted that, until October 2011, 1151 institutions throughout 64 countries and regions (excluding China) around the world offered animation education. Furthermore, the number of this kind of institution in China has been the top position in the world. (See Table 1).

Table 1 Numbers of animation institution by countries

\begin{tabular}{|c|c|c|c|c|c|}
\hline & Country & Number & & Country & Number \\
\hline 1 & U.S.A & 401 & 6 & New Zealand & 27 \\
\hline 2 & India & 264 & 7 & France & 26 \\
\hline 3 & Canada & 99 & 8 & Australia & 25 \\
\hline 4 & U.K & 52 & 9 & Italy & 18 \\
\hline 5 & Germany & 30 & 10 & Belgium & 16 \\
\hline
\end{tabular}

Source: Su Feng and Luo Xiaoyi. "The mode of world animation education and development mechanism”. International Journal of Comic Art. Vol.14, No.2, pp.393-418, August 2012

The data above suggests that the number of higher education graduates has far exceeded the actual capacity of Chinese animation industry. Meanwhile, as of 2000, leading companies within the industry strive to carry out the non-academic training, almost simultaneously with the academic education in colleges. The non-academic training provides qualified staff for the company itself, but also contributes an important source of profit. This situation makes the mismatch between the supply from college and demand of industry even worse.

- Mismatch between higher education model and demand for talent

Nowadays, the main source of profit of more than $90 \%$ animation companies is contributed from the outsourcing of contracts. And the talent demand from them is mainly skillful technicians. However, the graduates provided by higher education nowadays mismacth this demand. First of all, the aim of most universities, which belong to the kind of comprehensive model, is cultivating creative and versatile talent. It makes not much contribution to making cost reduction and quality improvement in the outsourcing contract. Secondly, it is difficult for the minor skill-based colleges to achieve their goals of talent education, due to the weak background of students as well as the lack of high-level faculty. It can be said that most of the graduates are not capable enough to reduce the production cost or improve the production quality, or to enhance the originality or create profitable production.

- Mismatch between curriculum setting and upcoming upgrading within industry

The Chinese animation industry has already experienced the stage of exporting outsourcing for 25-plus years, and is transforming to the stage of exporting of feature. However, the curriculum setting in existing college does not move forward along with the process of industrial development. It leads to the situation that the "creative and versatile" graduates cannot satisfy the demand from animation companies, to say nothing of the demand in the upcoming future. Therefore, for the producing process, increasing the curriculum focus on pre-production and post-production should be taken into consideration. The higher education should provide creative talent in the fields of planning, animation screenwriting, composition, and dubbing to service the production of feature film. In the future, talents in technology, management, and law who can adapt to the industry upgrading, are also needed. These talents can help to build industrial competitiveness, as well as improve the industrial chain. Only by taking all the requirements into account, can higher animation education provide qualified talents to the transforming and upgrading industry.

It is obvious that both of Chinese higher animation education and industry are still in their infancies, still in the period of exploration, without a dominant development mode, and have experience a "blowout" growth. Under this circumstance, our higher animation education is neither conducive to enhancing the competitiveness at outsourcing, nor does it help to foster the capacity of sustainable development of animation industry. This situation results in the structural contradiction. A vicious circle is formed between the education and talent demand from industry. 


\section{III.COUNTERMEASURES: CLUSTER GROWTH}

Under the context of the trend of world animation education which provides reference and template for China, we diagnose our animation industry based on the theories of industrial cluster. The talent requirements of the animation industry are identified, from which we provide the basic principle of developing our higher animation education.

\section{A. Animation Ontology: for technology advance}

With the advance of technology new animation forms are emerging, such as mobile phone animation, flash animation, and web animation. These forms of animation, based on creativity, are transformed from entertainment to commercial usage. They are applied to various fields, such as film and television, games, education, military, aerospace, construction, and medical service. In this circumstance, higher animation education should take the trend of "grand animation" into consideration; broaden the scope of animation ontology; specify the curriculum setting and cultivate various types of animation talent specific to different target markets.

\section{B. Curriculum setting: face the whole industrial chain}

Considering the whole process of industrial chain, the curriculum setting should carry out multi-disciplinary research and instruction on the two levels, the level of production and the one of industrial chain. For the first level, higher education should cultivate more creative screenwriters, composers, dubbing artists to complete the talent structure as well as improve the production level of animation. On the second level, animation schools should provide the whole industrial chain talented individuals who have a good command of technology, management, law, and so on. More specifically, it is beneficial to enhance the innovation, both in products and business, if students are familiar with the development trend of new technology. Introducing the general management theory to the animation industry is conducive to broadening the students` knowledge of marketing, financial, operation and human resource management, and further, helpful to train the senior managers and entrepreneurs in the industry. Students would have a good awareness of law if related curricula are offered at universities.

\section{Talent structure: face the dynamic of industrial development}

The demand of talent changes, depending on the stage that the animation industry is on. It shows in two aspects. Firstly, the demand has different biases in different stage of the industry. In the export outsourcing stage, the highlight of the industry lies in the production period specifically, technician and management talent are needed. In the stage of export of feature, the industry emphasizes the whole production process as well as the overall industrial chain. Therefore, more creative talent is needed compared to the previous stage. While in the stage of import outsourcing, the technicians are squeezed out from the mainstream labor market since the production part is transferred to low-cost countries. Secondly, in different stage, even for the same type of personnel, the emphasis of their job content and required skill is different. Take the management personnel for instance; their main job content in the export outsourcing stage is decreasing cost. While in the export of feature stage and import outsourcing stage, the focus changes to mobilize all kinds of talent inside the company; foster the creativity, and meet the demand from the domestic and overseas markets. Thus, for the current Chinese animation industry, the cultivation of technicians is consistent with the stage of outsourcing export. Furthermore, the creative talent is educated for the upcoming stage of export of feature. The management talent plays a crucial role on both the current and future development of animation industry. Above all, the animation education should keep a tight eye on the trend of development of animation, carefully diagnose the talent demand, timely adjust the plan of talent cultivation, and keep the animation education dynamic.

Table 2 Stage of animation industry and demand for talent

\begin{tabular}{|c|c|c|}
\hline No. & Stage & Demand for Talent \\
\hline 1 & Export Outsourcing & Manager, Technician \\
\hline 2 & Export of feature & Creator, Manager, Technician \\
\hline 3 & Import Outsourcing & Creator, Manager \\
\hline
\end{tabular}

Above all, from the macro perspective, the blind expansion of animation education brings pressure on employment. Meanwhile, the continuously dynamic demand of talent challenges the higher education. These situations require that the animation schools should grasp the demand trend of talent so that they can survive the competition. From the micro perspective, animation colleges should properly arrange and update their course content and curriculum setting consistent with the current situation and future trend of animation industry. Only after making clear the relationship between demand and supply for talent, can the animation industry overcome the obstacle, and develop. Only in this way can Chinese higher animation education obtain a comprehensive breakthrough and achieve a qualitative leap!

\section{ACKNOWLEDGMENT}

This paper is sponsored by the project (12BGL133) of National fund of philosophy and social science.

\section{REFERENCES}

[1] Zhao Ce, “Animation Education meets awkward,” China High-Tech Industry Herald, July 5, 2010.

[2] Ma Zilei, “ Chinese Animation Education encounters bottle-neck of development,” China Culture Daily, July 19, 2010.

[3] Xiao Yongliang, "Analysis on Current Chinese Animation Education System," Journal of Beijing Union University (Humanities and Social Science),pp.71-77,September 2011

[4] Porter M, “The Competitive Advantage of Nations," New York: The Free Press, 1990.

[5] Su Feng, "Research on International Trade Mode of Animation, ” Ph.D. Dissertation, School of Management, Harbin Institute of Technology,2006.

[6] Jin Yuanpu and Zhuang Pengtao, "Grand Animation Seeks for a Wider Space,” Hundred Schools in Arts, PP.36-46, 2012. 